\title{
Vitamin D insufficiency in neonatal hypoxic-ischemic encephalopathy
}

\author{
Danielle W. Lowe', Bruce W. Hollis', Carol L. Wagner', Thomas Bass², David A. Kaufman³, Michael J. Horgan4, \\ Laurence M. Givelichian ${ }^{5}$, Koravangatta Sankaran ${ }^{6}$, Jerome Y. Yager ${ }^{6}$, Lakshmi D. Katikaneni', Don Wiest ${ }^{1}$ and Dorothea Jenkins ${ }^{1}$
}

BACKGROUND: Vitamin D has neuroprotective and immunomodulatory properties, and deficiency is associated with worse stroke outcomes. Little is known about effects of hypoxiaischemia or hypothermia treatment on vitamin D status in neonates with hypoxic-ischemic encephalopathy (HIE). We hypothesized vitamin D metabolism would be dysregulated in neonatal HIE altering specific cytokines involved in Th17 activation, which might be mitigated by hypothermia.

METHODS: We analyzed short-term relationships between $25(\mathrm{OH})$ and $1,25(\mathrm{OH})_{2}$ vitamin $\mathrm{D}$, vitamin D binding protein, and cytokines related to Th17 function in serum samples from a multicenter randomized controlled trial of hypothermia 33 ${ }^{\circ} \mathrm{C}$ for $48 \mathrm{~h}$ after HIE birth vs. normothermia in 50 infants with moderate to severe HIE.

RESULTS: Insufficiency of $25(\mathrm{OH})$ vitamin D was observed after birth in $70 \%$ of infants, with further decline over the first $72 \mathrm{~h}$, regardless of treatment. $25(\mathrm{OH})$ vitamin D positively correlated with anti-inflammatory cytokine IL-17E in all HIE infants. However, Th17 cytokine suppressor IL-27 was significantly increased by hypothermia, negating the IL-27 correlation with vitamin D observed in normothermic HIE infants.

CONCLUSION: Serum $25(\mathrm{OH})$ vitamin D insufficiency is present in the majority of term HIE neonates and is related to lower circulating anti-inflammatory IL-17E. Hypothermia does not mitigate vitamin D deficiency in HIE.

V itamin D is an important neurosteroid during development and after central nervous system (CNS) injury. Deficiency of vitamin $\mathrm{D}$ contributes to many diseases that involve systemic or CNS inflammation, and vitamin D-deficient adults have worse outcomes after stroke $(1,2)$. Most vitamin D studies in neonates have focused on its role in mineral metabolism. Little is known about vitamin D status, immunomodulatory function, or effects of hypothermia on vitamin D binding protein (DBP) in neonatal hypoxic-ischemic encephalopathy (HIE).
The significance of vitamin $\mathrm{D}$ as an immunomodulator and regulator of proinflammatory Th17 lymphocytes has been well established in adult stroke. Adult patients have demonstrated an increased proportion of Th17 lymphocytes within $24 \mathrm{~h}$ (3) and $1 \mathrm{wk}$ after stroke (4). These findings may be pertinent to neonatal HI, as naive T cells develop into Th17 cells more readily in infants than adults, and may contribute to neonatal inflammatory response to HI injury (5). Vitamin D has been shown to reduce proinflammatory Th17 differentiation and proliferation, and IL-17 cytokine production (6), while promoting anti-inflammatory IL-10 and T regulatory cells (7). However, vitamin $\mathrm{D}$ degradation is increased in neuroinflammation (8), which may limit its effect as a Th17 immunomodulator after HI. In addition, vitamin D deficiency $(<20 \mathrm{ng} / \mathrm{ml})$ and insufficiency $(<30 \mathrm{ng} / \mathrm{ml})$ is widespread in human neonates (9). In the only other report on vitamin D status in neonatal HIE, Mutlu et al. demonstrated lower serum $25(\mathrm{OH})$ vitamin $\mathrm{D}(25(\mathrm{OH}) \mathrm{D})$ concentrations in 31 cooled HIE infants in Turkey compared with healthy term control infants (10). In this study, all HIE infants had serum $25(\mathrm{OH}) \mathrm{D}<20 \mathrm{ng} / \mathrm{ml}$ on day of life 1 , and $30 \%$ infants had persistently low serum $25(\mathrm{OH}) \mathrm{D}$ on day 5 .

Circulating concentrations of prohormone $25(\mathrm{OH}) \mathrm{D}$ are important for the maintenance of CNS concentrations of active $1,25(\mathrm{OH})_{2}$ vitamin $\mathrm{D}\left(1,25(\mathrm{OH})_{2} \mathrm{D}\right)$, which is synthesized in many extra-renal cells, including neuronal and glial cells that contain 1- $\alpha$-hydroxylase (11). Thus, serum concentrations of $25(\mathrm{OH}) \mathrm{D}$ may be crucial for vitamin D's neuroprotective and immune functions after $\mathrm{HI}$ injury, in addition to endocrine roles in calcium and phosphorus homeostasis $(2,12)$. We hypothesized that vitamin D metabolism would be increased with neonatal HIE, and that low serum 25(OH) D concentrations would adversely affect Th17 cytokines. We further hypothesized that hypothermia therapy would alter vitamin D metabolism and specific cytokines involved in Th17 activation. Using samples from neonates with moderate to severe HIE in the first $3 \mathrm{~d}$ after $\mathrm{HI}$ birth, we explored 25(OH)

\footnotetext{
'Department of Pediatrics, Medical University of South Carolina, Charleston, South Carolina; ${ }^{2}$ Department of Pediatrics, Eastern Virginia Medical School, Norfolk, Virginia; ${ }^{3}$ Department of Pediatrics, University of Virginia, Charlottesville, Virginia; ${ }^{4}$ Department of Pediatrics, Albany Medical Center, Albany, New York; ${ }^{5}$ Department of Pediatrics, University of Saskatchewan, Saskatoon, Saskatchewan, Canada; ${ }^{6}$ Department of Pediatrics, University of Alberta, Edmonton, Alberta, Canada. Correspondence: Dorothea Jenkins (jenkd@musc.edu)

This work was published in abstract form and presented at the Pediatric Academic Societies Annual Meeting. Vancouver, BC, May 2014 and San Diego, CA, April 2015.Clinical Trials Registration \#: NCT02826941
} 
$\mathrm{D}$ and $1,25(\mathrm{OH})_{2} \mathrm{D}$ serum concentrations, vitamin $\mathrm{D}$ binding proteins (DBP and albumin), and circulating cytokines related to Th17 function in addition to calcium and phosphorus relationships.

\section{METHODS}

We investigated serum $25(\mathrm{OH}) \mathrm{D}, 1,25(\mathrm{OH})_{2} \mathrm{D}$, DBP, albumin, Th17related cytokines, calcium, and phosphorus concentrations in serum samples stored at $-80^{\circ} \mathrm{C}$ from a multicenter randomized trial (RCT) of systemic hypothermia in neonates with HIE (13). This study was approved by Institutional Review Boards at all seven participating centers (Medical University of South Carolina, Eastern Virginia Medical School, University of Virginia, Albany Medical Center, State University of New York, Medical College of Georgia, and University of Saskatchewan). Entry criteria and demographic data of this cohort have been published in detail (13). Briefly, newborn infants were at least $35 \mathrm{wk}$ gestation, 2,000 g birth weight, and less than $6 \mathrm{~h}$ after birth or HI injury, with signs of moderate to severe neonatal encephalopathy, and were randomization to either hypothermia (rectal temperature, $\left.T_{r}=33{ }^{\circ} \mathrm{C}\right)$ or normothermia $\left(T_{r}=36.5^{\circ} \mathrm{C}\right)$ treatment for $48 \mathrm{~h}$ after parental consent. Infants with maternal chorioamnionitis, sepsis, and birth weight or head circumference less than $10 \%$ were excluded from the study.

\section{Multiplex and Vitamin D Assays}

Serum samples were collected at enrollment and every $12 \mathrm{~h}$ for $72 \mathrm{~h}$. Hypothermia was initiated by transport teams at outside hospitals, and most hypothermia infants were cooled for several hours at the time of the first blood draw within $9 \mathrm{~h}$ of birth. Study time points after enrollment correspond to time after birth (in parentheses) as follows: Enrollment $0 \mathrm{~h}(0-9 \mathrm{~h}), 12 \mathrm{~h}(12-21 \mathrm{~h}), 24 \mathrm{~h}(22-33 \mathrm{~h}), 36 \mathrm{~h}(24-45 \mathrm{~h})$, $48 \mathrm{~h}(46-57 \mathrm{~h}), 60 \mathrm{~h}(58-69 \mathrm{~h})$, and $72 \mathrm{~h}(70-81 \mathrm{~h})$. Samples at the 60$72 \mathrm{~h}$ after enrollment were obtained after rewarming. Samples were aliquoted and stored at $-80{ }^{\circ} \mathrm{C}$ until assay in duplicate on a BioPlex platform for the following analytes: IL-17A, IL-17E, IL-17F, IL-21, IL-22, IL-23, IL-27, and TNF- $\beta$ (HTH17MAG-14K, EMD Millipore, Billerica, MA) as previously described (14). Concentrations were based on 5 parameter logistic fit of a 7-point standard curve. Serum levels of IL-17F, IL-22, IL-23, and TNF- $\beta$ were below detectible limits, and IL-21 was only analyzed up to $12 \mathrm{~h}$ due to low numbers of patients with detectible levels after this time.

$25(\mathrm{OH}) \mathrm{D}$ and $1,25(\mathrm{OH})_{2} \mathrm{D}$ levels were measured in available samples from 0 to $72 \mathrm{~h}$ after hypothermia initiation using a rapid, direct radioimmunoassay in Dr. Hollis' laboratory with a lower limit of detection of $2 \mathrm{ng} / \mathrm{ml}$ for $25(\mathrm{OH}) \mathrm{D}$ and $15 \mathrm{pg} / \mathrm{ml}$ for $1,25(\mathrm{OH})_{2} \mathrm{D}$, as previously described (15). DBP was measured on available serum samples using a 1:5,000 dilution in a sandwich ELISA (GWB-DM3741, Genway Biotech, San Diego, CA) according to manufacturer's protocol. Lower limit of detection of the DBP assay was $6.5 \mathrm{ng} / \mathrm{ml}$. On a subset of samples $(n=17)$ from HIE infants at the Medical University of South Carolina, we performed a chart review and determined daily vitamin $\mathrm{D}$ intake in total parenteral nutrition (TPN) for the first $72 \mathrm{~h}$ (pediatric multivitamins, ergocalciferol $400 \mathrm{IU} / \mathrm{d}=10 \mathrm{mcg} / \mathrm{d}$ or $417 \mathrm{ng} / \mathrm{h})$.

\section{Clinical Labs}

Cord or initial neonatal gases were obtained at or within $1 \mathrm{~h}$ of birth (13). Enrollment calcium, phosphorus, albumin, and $\mathrm{pH}$ were all obtained after arrival at the tertiary care center, between 3 and $9 \mathrm{~h}$ of life. Arterial blood gases were measured every $6 \mathrm{~h}$, calcium and phosphorus levels were measured every $12 \mathrm{~h}$, and albumin levels were measured every $24 \mathrm{~h}$ over the first $4 \mathrm{~d}$ of life. Enteral nutrition was not started until $96 \mathrm{~h}$ after HI birth.

\section{Statistical Analysis}

Data are reported as medians \pm interquartile range (IQR) or graphically as medians $\pm 95 \%$ confidence intervals (CI). Mann-Whitney $U$-test or Wilcoxon signed rank was used for vitamin D comparisons as appropriate. Racial analyses were restricted to Caucasian and African American groups as others were too few to analyze. Correlations within individuals were analyzed using a Spearman rank correlation with reported significance $P \leq 0.01$, to account for multiple comparisons. The independent effects of 25(OH)D and $1,25(\mathrm{OH})_{2} \mathrm{D}$ on repeated laboratory measures, and the independent and interaction effects of hypothermia treatment, time, and survival on laboratory measurements were assessed using mixed effects modeling with pairwise post-hoc analyses. The effects of albumin and DBP on $25(\mathrm{OH}) \mathrm{D}$ levels were also assessed using mixed model analysis with treatment and time in the model. Within the treatment groups, IL-27 was assessed over time using a mixed model. All analyses were performed using SPSS 21 (IBM, Armonk, NY).

\section{RESULTS}

Demographics of the 50 patients included in this analysis were similar between hypothermia $(n=28)$ and normothermia $(n=22)$ groups (Table 1). Severe outcome (death or Bayley II psychomotor developmental indices $\leq 70$ at $12 \mathrm{mo}$ ) was significantly more common in normothermia compared to hypothermia infants (Fisher's exact test, $P=0.036$ ).

\section{Vitamin D Deficiency Is Common And Declines Further Over $72 \mathrm{~h}$ In Infants With Hypoxic-Ischemic Injury}

Median serum 25(OH)D levels were not significantly different between normothermic $(17.5 \mathrm{ng} / \mathrm{ml}$; IQR 7.5, $21.3 \mathrm{ng} / \mathrm{ml})$ and hypothermic HIE infants $(16.8 \mathrm{ng} / \mathrm{ml}$; IQR 9.4, $20.8 \mathrm{ng} / \mathrm{ml})$ at any time point, nor between Sarnat stages 2 and $3(P=0.897)$ or sex $(P=0.742)$. Median serum 25(OH)D were significantly lower in African American vs. Caucasian infants, regardless of treatment (Mann-Whitney, $P=0.001$, Figure 1a) (9). Several sites in this multicenter RCT were in more northern latitudes: there were six infants from the Canadian site (two Native American, four Caucasian), four from Albany (four Caucasian), and two from SUNY Brooklyn (one African American, one Asian). The means and SD of infants from northern latitude sites were Canada $24.7 \pm 11.3$ (range $12.3-39.7 \mathrm{ng} / \mathrm{ml}$ ), Albany $18.5 \pm 3.0$ (range $14.7-21.5 \mathrm{ng} / \mathrm{ml}$ ), and SUNY $13.7 \pm 5.7$ (range $9.7-17.7 \mathrm{ng} / \mathrm{ml}$ ). Also comparing northern

Table 1. Study demographics

\begin{tabular}{|c|c|c|c|}
\hline & Hypothermia & Normothermia & Total \\
\hline & $N=28$ & $n=22$ & $n=50$ \\
\hline \multicolumn{4}{|l|}{ Gender } \\
\hline Male & $16(57 \%)$ & $11(50 \%)$ & $26(54 \%)$ \\
\hline \multicolumn{4}{|l|}{ Race } \\
\hline Caucasian & $16(57 \%)$ & $13(59 \%)$ & $29(58 \%)$ \\
\hline African-American & $10(36 \%)$ & $7(32 \%)$ & $17(34 \%)$ \\
\hline Other & $2(7 \%)$ & $2(9 \%)$ & $4(8 \%)$ \\
\hline \multicolumn{4}{|l|}{ Sarnat } \\
\hline Stage I & $0(0 \%)$ & $1(5 \%)$ & $1(2 \%)$ \\
\hline Stage II & $4(14 \%)$ & $4(18 \%)$ & $8(16 \%)$ \\
\hline Stage III & $24(86 \%)$ & 17 (77\%) & 41 (82\%) \\
\hline \multicolumn{4}{|l|}{ Outcome } \\
\hline Death & $9(32 \%)$ & $8(36 \%)$ & $17(34 \%)$ \\
\hline $\begin{array}{l}\text { Death or PDI } \leq 70 \\
\text { @ } 12 \mathrm{mo}\end{array}$ & $14(50 \%)^{*}$ & $18(77 \%)$ & 32 (64\%) \\
\hline
\end{tabular}



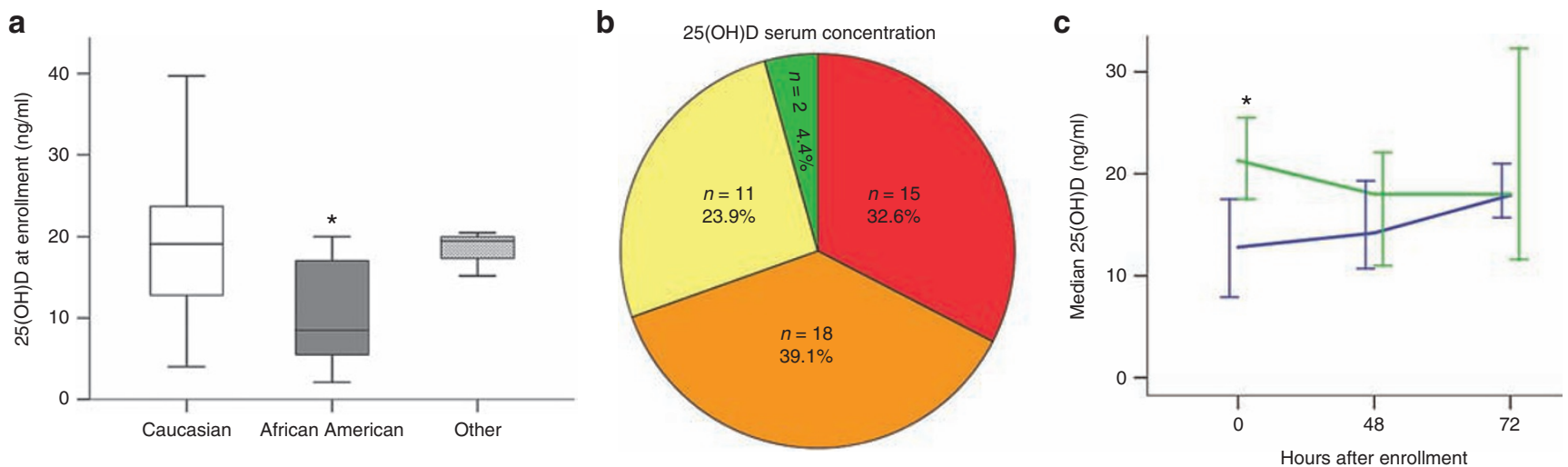

Figure 1. Circulating $25(\mathrm{OH}) \mathrm{D}$ at enrollment after hypoxic-ischemic $(\mathrm{HI})$ injury $(n=46)$. (a) Box plots of median, $25^{\text {th }}$ and $75^{\text {th }}$ interquartile range, and ranges of serum $25(\mathrm{OH}) \mathrm{D}$ by race in HIE infants ( $n=27$ Caucasian, 16 African American, 3 other race; ${ }^{*} P=0.001$ vs. Caucasian). (b) Incidence of sufficiency ( $\geq 30 \mathrm{ng} / \mathrm{ml}$, green), low-sufficiency (20-30 ng/ml, yellow), insufficiency (12-20 ng/ml, orange) and deficiency $(<12 \mathrm{ng} / \mathrm{ml}$, red) of $25(\mathrm{OH}) \mathrm{D}$. (c) Median $( \pm$ $95 \% \mathrm{Cl}$ ) serum $25(\mathrm{OH}) \mathrm{D}$ levels over $72 \mathrm{~h}$ in HIE patients that either maintained serum $25(\mathrm{OH}) \mathrm{D}$ levels during the study period $(n=17$, blue) or had declining serum $25(\mathrm{OH}) \mathrm{D}\left(n=17\right.$, green) at $48-72 \mathrm{~h}$ compared to enrollment $\left({ }^{*} P=0.002\right)$.

and southern latitude Native American/African American (northern $14.9 \pm 4.9 \mathrm{ng} / \mathrm{ml}, n=3$; southern $10.4 \pm 6.3 \mathrm{ng} / \mathrm{ml}, n$ $=17$ ) and Caucasian infants (northern $20.8 \pm 9.9, n=8$; southern $18.4 \pm 6.9 \mathrm{ng} / \mathrm{ml}, n=23$ ), the means were not significantly different in the two latitudes by race, though sample size was more limited in northern latitudes.

Treatment groups were subsequently combined for analysis of $25(\mathrm{OH}) \mathrm{D}$ ( $n=46$ infants with enrollment $25(\mathrm{OH}) \mathrm{D}$ concentrations). Circulating $25(\mathrm{OH}) \mathrm{D}$ at $0 \mathrm{~h}$ was categorized within consensus guidelines for nutritional rickets but taking into account other levels that have implications for immune function $(15,16)$ : sufficient $(>30 \mathrm{ng} / \mathrm{ml} ;>75 \mathrm{nmol} / \mathrm{l})$, low-sufficient ( $>20-30 \mathrm{ng} / \mathrm{ml} ; 50-75 \mathrm{nmol} / \mathrm{l})$, insufficient $(12-20 \mathrm{ng} / \mathrm{ml}$; $30-50 \mathrm{nmol} / \mathrm{l})$, and deficient $(<12 \mathrm{ng} / \mathrm{ml} ;<30 \mathrm{nmol} / \mathrm{l})$.

$25(\mathrm{OH}) \mathrm{D}$ was insufficient in $72 \%$ of HIE infants immediately after birth, and 33\% of HIE infants were deficient (Figure 1b). Only $28 \%$ had $25(\mathrm{OH}) \mathrm{D}$ levels $>20 \mathrm{ng} / \mathrm{ml}$, and two infants (4\%) had 25(OH)D levels between 30 and $40 \mathrm{ng} / \mathrm{ml}$. All African American HIE infants had 25(OH)D levels $\leq 20 \mathrm{ng} / \mathrm{ml}$. These levels are in contrast to reported cord blood $25(\mathrm{OH}) \mathrm{D}$ concentrations in healthy, term neonates in whom $56 \%$ were deficient and mean $25(\mathrm{OH}) \mathrm{D}$ was $21.1 \pm 2.2 \mathrm{ng} / \mathrm{ml}(15)$.

Serum $25(\mathrm{OH}) \mathrm{D}$ concentrations decreased further in $50 \%$ of HIE infants between enrollment and $48-72 \mathrm{~h}(n=17$ out of 34 infants with multiple measurements; Figure 1c).

We next evaluated a subset of infants $(n=17)$ with serial $25(\mathrm{OH}) \mathrm{D}$ levels in whom documentation of exogenous parenteral administration of $25(\mathrm{OH}) \mathrm{D}$ in multivitamins was available, to determine the effect on serum $25(\mathrm{OH}) \mathrm{D}$ in the acute phase after HI birth. Nine infants received $400 \mathrm{IU}(10 \mu \mathrm{g})$ ergocalciferol per day in TPN at a constant infusion rate of $417 \mathrm{ng} / \mathrm{h}$, starting at a median of $35 \mathrm{~h}$ (range 3-67 h). Five out of nine infants had lower serum $25(\mathrm{OH}) \mathrm{D}$ at $48 \mathrm{~h}$, which continued to decline to $72 \mathrm{~h}$ in two of these infants (Supplementary Figure S1 online). For all supplemented infants, the change in serum $25(\mathrm{OH}) \mathrm{D}$ varied from -1 to $+3.7 \mathrm{ng} / \mathrm{ml}$ at $72 \mathrm{~h}$, indicating little or no accumulation of $25(\mathrm{OH}) \mathrm{D}$ in the first $3 \mathrm{~d}$ after HIE.

\section{Active Hormone $1,25(\mathrm{OH})_{2} \mathrm{D}$ Is Undetectable in a Third of HIE Infants}

Circulating active $1,25(\mathrm{OH})_{2} \mathrm{D}$ concentrations are maintained by renal conversion of serum $25(\mathrm{OH}) \mathrm{D}$ by 1 - $\alpha$-hydroxylase, which is regulated by parathyroid hormone and calcium and phosphorus levels under normal physiologic conditions (17). We investigated $1,25(\mathrm{OH})_{2} \mathrm{D}$ levels after HIE on a more limited set of serum samples from $0-12 \mathrm{~h}(n=16), 36-48 \mathrm{~h}(n=14)$, and $60-72 \mathrm{~h}(n=10)$. Six of 16 HIE infants $(38 \%)$ had undetectable levels of $1,25(\mathrm{OH})_{2} \mathrm{D}$ within $12 \mathrm{~h}$ of birth $(<15 \mathrm{pg} / \mathrm{ml})$. Among those with detectable serum levels, $1,25(\mathrm{OH})_{2} \mathrm{D}$ concentrations were not different than that reported in healthy infants (median $37 \mathrm{pg} / \mathrm{ml}$ (IQR 15, $50 \mathrm{pg} / \mathrm{ml}, 0-12 \mathrm{~h}$ ) (15), nor between treatment groups. Median serum $1,25(\mathrm{OH})_{2} \mathrm{D}$ gradually increased to 41 $\mathrm{pg} / \mathrm{ml}$ at $36-48 \mathrm{~h}(\mathrm{IQR} 15,51 \mathrm{pg} / \mathrm{ml}, n=14)$ and $51 \mathrm{pg} / \mathrm{ml}$ at $60-72 \mathrm{~h}(\mathrm{IQR} 18,85 \mathrm{pg} / \mathrm{ml}, n=10)$. The number of HIE infants with undetectable $1,25(\mathrm{OH})_{2} \mathrm{D}$ also declined over this period to 4 $(28 \%)$ at $36-48 \mathrm{~h}$ and $2(20 \%)$ at $60-72 \mathrm{~h} .1,25(\mathrm{OH})_{2} \mathrm{D}$ concentrations were not related to the serum $25(\mathrm{OH}) \mathrm{D}$ or DBP at any time point, which may be due to a smaller sample size for $1,25(\mathrm{OH})_{2} \mathrm{D}$ and/or preferential binding of DBP to $25(\mathrm{OH}) \mathrm{D}(12)$.

\section{Low Vitamin D Binding Protein is Associated with Serum 25(OH) D Status}

The bioavailability of circulating lipophilic vitamin $\mathrm{D}$ may be determined by binding either to DBP, which has high affinity for $25(\mathrm{OH}) \mathrm{D}$, or to serum albumin, which is 100 times more abundant (12). In HIE, lower serum albumin and perhaps lower DBP might make more lipophilic 25(OH)D available for tissue uptake or renal conversion. Hypothermia treatment group had significantly lower serum albumin concentrations when compared to normothermia groups over the study period $(P<0.0001)$. Albumin concentrations were positively correlated with serum $25(\mathrm{OH}) \mathrm{D}$ levels in the hypothermia group at both 0 and $72 \mathrm{~h}(P \leq 0.016)$ (Figure 2a). Interestingly, in the normothermic HIE group, albumin and 25(OH)D levels were not significantly related. 


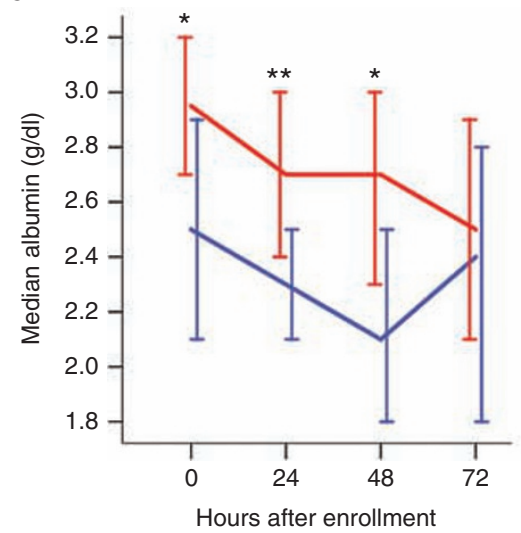

b

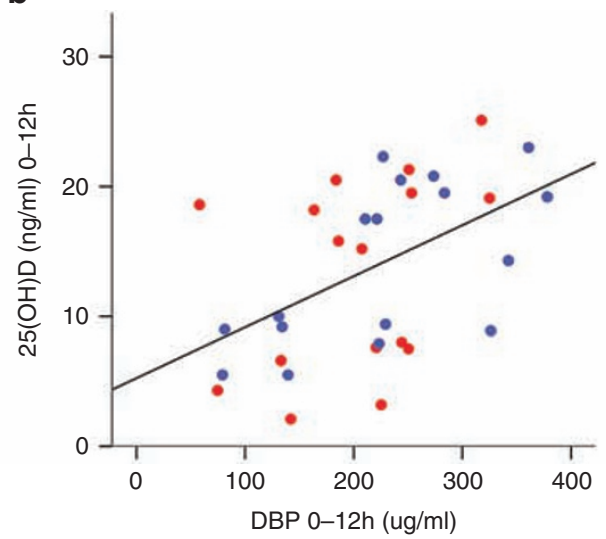

C

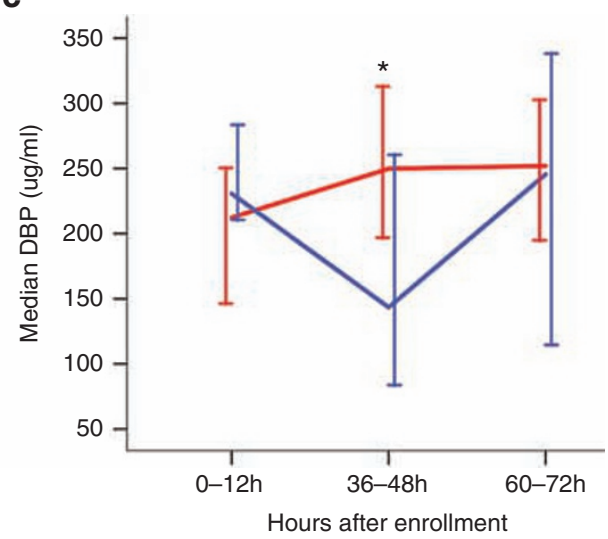

Figure 2. Circulating vitamin D binding proteins by hypothermia (blue) and normothermia (red) treatment. (a) Median serum albumin over time ( $n=50$, $\left.{ }^{*} P<0.01,{ }^{* *} P<0.001\right)$; (b) Serum vitamin D binding protein (DBP) vs. $25(\mathrm{OH}) \mathrm{D}$ concentrations at $0-12 \mathrm{~h}$ after enrollment $(n=33, \mathrm{rho}=0.503, P=0.003) ;(\mathbf{c})$ Median serum DBP over time by hypothermia and normothermia treatment. ${ }^{*} P<0.05$.

Mean DBP was lower after moderate to severe HI birth $(215 \pm 85 \mu \mathrm{g} / \mathrm{ml}, n=33)$ in our study than previously reported in normal term and preterm infant cord blood (285 and 297 $\mu \mathrm{g} / \mathrm{ml}$, respectively) $(18,19)$, and positively correlated with serum $25(\mathrm{OH}) \mathrm{D}$ at $0-12 \mathrm{~h}$ (Spearman's Rho $\geq 0.503, P \leq 0.006$, $n=33$, Figure $2 \mathbf{b}$ ). DBP did not differ by treatment group at $0-12 \mathrm{~h}$ of age, or by those who had declining vs. increasing serum $25(\mathrm{OH}) \mathrm{D}$. However, during hypothermia treatment at $36-48 \mathrm{~h}$, circulating DBP was significantly lower in hypothermic HIE infants $(P=0.004$, Figure 2c). After rewarming $(60-72 \mathrm{~h}, n=27)$ DBP rebounded in the hypothermia group, equivalent to normothermic concentrations.

We performed mixed model analyses to determine whether DBP or albumin was more influential on serum 25(OH)D levels, with treatment in the model. At both $0-12$ and $60-72 \mathrm{~h}$, DBP predicted $25(\mathrm{OH}) \mathrm{D}$ serum concentrations $(P \leq 0.045)$, without significant contribution from albumin when DBP was included. At 36-48 h, hypothermia treatment and DBP had an interaction effect in predicting serum $25(\mathrm{OH}) \mathrm{D}$. This interaction effect is consistent with our simple correlational analyses in which hypothermia treatment decreased DBP at 36-48 h, but did not have an independent effect on serum $25(\mathrm{OH}) \mathrm{D}$ concentrations in addition to its effect on DBP. These results are the first reports of DBP levels after HIE and suggest a complex relationship of direct and indirect effects of HIE and hypothermia on DBP levels in these infants.

\section{Vitamin D Correlates With Anti-inflammatory Th17 Regulatory Cytokines}

Vitamin D is known to decrease Th17 activation in other inflammatory conditions (20). Th17-activated cells produce proinflammatory IL-17A and IL-17F, while IL-17E suppresses Th17 cell proliferation and activation (21). IL-27, produced by neonatal macrophages, also inhibits Th-17 induction and is regulated by vitamin $\mathrm{D}(22,23)$. Therefore, we next examined vitamin D's relationship to proinflammatory Th17 cytokines (IL-17A, IL-17F, IL-21, MIP3 $\alpha$ ) and anti-inflammatory IL-17E and IL-27 after moderate to severe HI injury.
Median serum cytokine levels for IL-17A, IL-21, MIP3 $\alpha$, and IL-17F were similar between treatment groups and were not associated with serum $25(\mathrm{OH}) \mathrm{D}$ levels immediately after HI birth (Supplementary Table S1 online). However, 25(OH) $\mathrm{D}$ levels at $48 \mathrm{~h}$ showed a significant correlation with antiinflammatory IL-17E serum concentrations at 60-72 h $(n=20$, Figure 3a).

Hypothermia treatment had a significant main effect $(P<$ $0.0001)$ on IL-27 serum concentrations and an interaction effect with time $(P=0.008)$, as illustrated in Figure $\mathbf{3 b}$, where IL-27 levels were significantly higher in hypothermia treated infants before and after rewarming, from 36 to $72 \mathrm{~h}$ (Figure $3 \mathbf{b}$ ). Serum IL-27 strongly correlated with $25(\mathrm{OH}) \mathrm{D}$ concentrations at $48 \mathrm{~h}$ in normothermic patients (Figure 3c), but not in the hypothermic infants (Figure 3d), consistent with a direct effect of hypothermia on production of IL-27, independent of 25(OH)D.

\section{Vitamin D's Relationship to Serum Phosphorus and Total Calcium Levels After HIE}

Vitamin D's role in calcium and phosphorus metabolism after moderate to severe HI has not been explored. Although there was marked variability in serum calcium, mean total and ionized calcium concentrations were significantly lower in hypothermic infants after rewarming at $60-72 \mathrm{~h}$ compared with normothermic infants $(P \leq 0.013)$, while serum phosphorus and $\mathrm{pH}$ were not different by treatment group (Supplementary Figure S2 online). Phosphorus concentrations were negatively correlated with $\mathrm{pH}(P<0.001)$ at $0 \mathrm{~h}$, supporting higher serum phosphorus as a marker of metabolic acidosis and perhaps injury severity.

Active $1,25(\mathrm{OH})_{2} \mathrm{D}$ controls circulating calcium and phosphorus levels under normal conditions, but after HIE neither were predicted by $1,25(\mathrm{OH})_{2} \mathrm{D}$ serum concentrations $(n=16)$, using mixed model analysis. Total serum calcium was positively predicted by serum $25(\mathrm{OH}) \mathrm{D}$ at $0 \mathrm{~h}(P=0.034)$, but not at 48 and $72 \mathrm{~h}$, perhaps due to intravenous calcium replacement therapy in 35 infants to correct initial hypocalcemia. 
Serum phosphorus was positively predicted by serum $25(\mathrm{OH})$ $\mathrm{D}$ concentration after $\mathrm{pH}$ had normalized at 48 and $72 \mathrm{~h}(P \leq$ $0.025)$. These data suggest that vitamin D's role in phosphorus homeostasis is functional 2-3 d after HI birth.
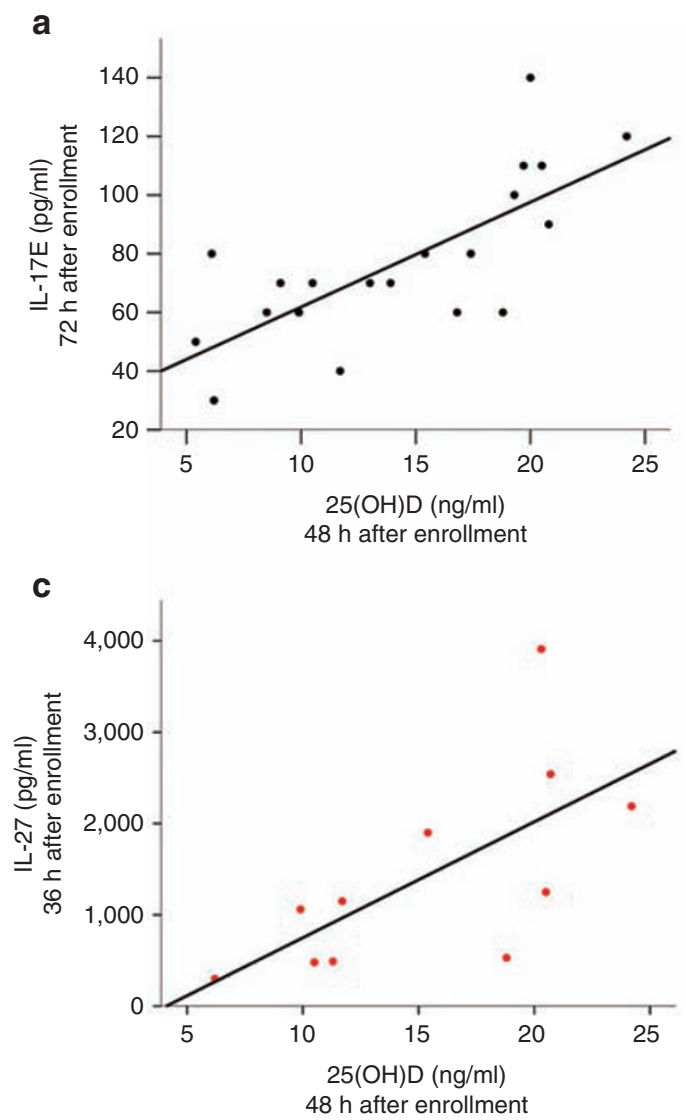

Survival Relates to Serum Phosphorus But not 25-OH Vitamin D Infants who died in the neonatal period had significantly lower $\mathrm{pH}(P=0.0002)$ and higher serum phosphorus over the $72 \mathrm{~h}$ study period than those who survived $(P=0.00006$,
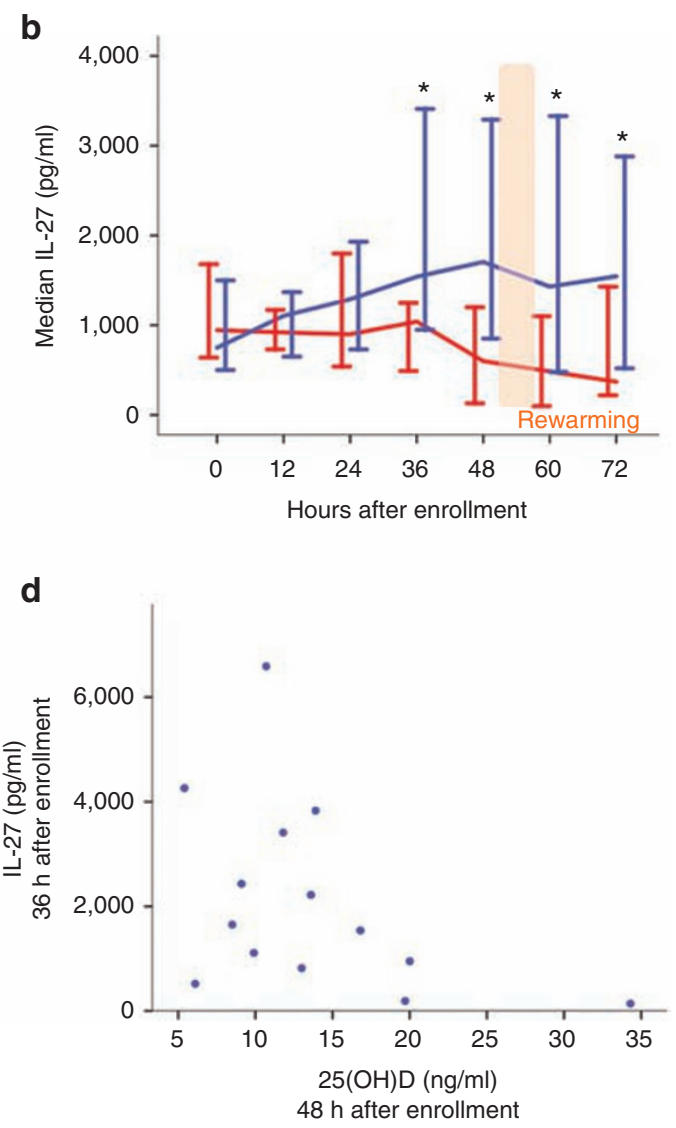

Figure 3. Anti-inflammatory cytokines IL-17E and IL-27 in hypoxic-ischemic encephalopathy (HIE) neonates. (a) $25(\mathrm{OH}) \mathrm{D}$ at $48 \mathrm{~h}$ correlates with IL-17E at $72 \mathrm{~h}$ after enrollment (rho $=0.555, P=0.001)$. (b) Median IL-27 $( \pm 95 \% \mathrm{Cl}, \mathrm{pg} / \mathrm{ml}$ ) over time in hypothermia (blue) and normothermia (red) treatment groups. $* P<0.05$, mixed model post-hoc analysis. (c) IL-27 at $36 \mathrm{~h}$ positively correlates with $25(\mathrm{OH}) \mathrm{D}$ in normothermic infants $(n=11$, rho $=0.809, P=$ 0.003). (d) IL-27 at $36 \mathrm{~h}$ does not correlate with $25(\mathrm{OH}) \mathrm{D}$ in hypothermic infants $(n=14$, rho $=-0.442, P=0.114)$.

a

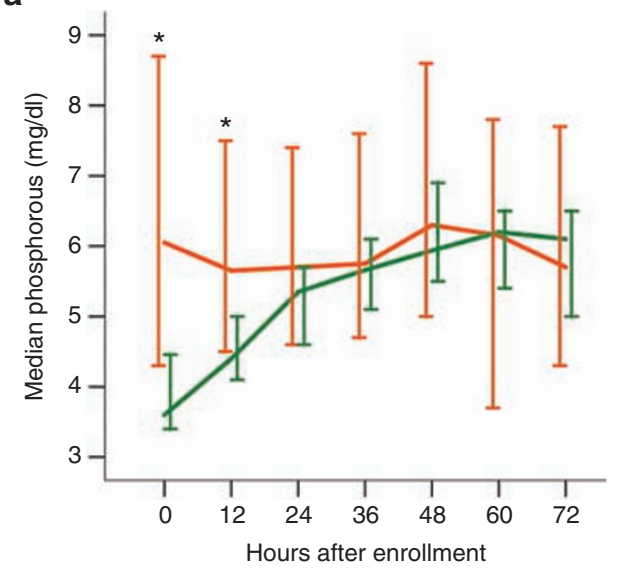

b

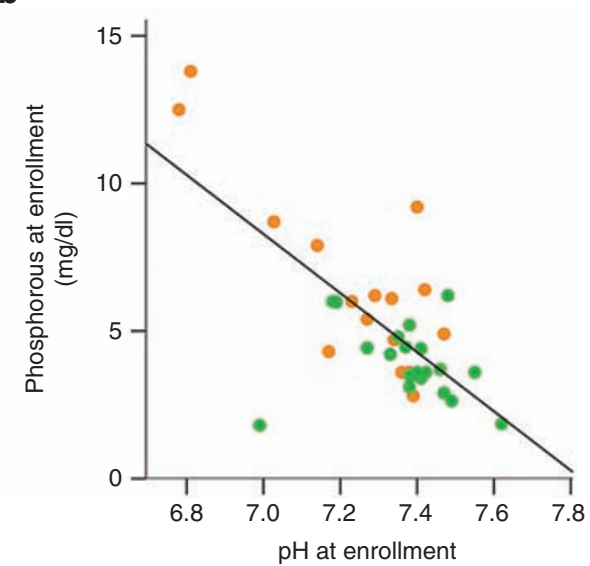

Figure 4. Phosphorous is significantly higher $3-12 \mathrm{~h}$ after birth in infants who do not survive (orange) the neonatal period compared to survivors (green). (a) Circulating median phosphorous $( \pm 95 \% \mathrm{Cl}$, * indicates $P<0.05)$ over $72 \mathrm{~h}$ after hypoxic-ischemic $(\mathrm{HI})$ birth. (b) Enrollment pH negatively correlates with phosphorous (rho $=-0.477, P=0.003$ ). 


\section{Articles | Lowe et al.}

Figure 4a) with a survival-time interaction for serum phosphorus $(P=0.041)$. This difference in serum phosphorus between surviving and nonsurviving HIE neonates was present at $0 \mathrm{~h}(P \leq 0.002)$, and negatively correlated with $\mathrm{pH}(P$ $=0.003$, Figure $4 \mathbf{b}$ ), supporting phosphorus as a marker of injury severity and poor outcome. Serum phosphorus concentrations of infants who survived were $<6.3 \mathrm{mg} / \mathrm{dl}$ within $9 \mathrm{~h}$ of birth.

Infants who had 25(OH)D deficiency at $0 \mathrm{~h}(<12 \mathrm{ng} / \mathrm{ml} ; n=$ $17)$ had a $58 \%$ survival rate similar to those with low or insufficient 25(OH)D $(12-30 \mathrm{ng} / \mathrm{ml} ; 65 \%$ survival, $n=31$, Fisher's exact test, $P=0.5)$. Both infants with sufficient $25(\mathrm{OH}) \mathrm{D}$ ( $>30 \mathrm{ng} / \mathrm{ml}$ ) survived (15). There was also no difference in survival between infants who maintained $(63 \%, n=26)$ compared to those who had decreasing $25(\mathrm{OH}) \mathrm{D}$ over $72 \mathrm{~h}(67 \%, n=11$, Fisher's exact test, $P=1.0)$. Therefore, serum $25(\mathrm{OH}) \mathrm{D}$ did not demonstrate a direct relationship with survival in this cohort of infants with severe HIE, and the sample size was too limited for further analysis of developmental outcome.

\section{DISCUSSION}

$25(\mathrm{OH}) \mathrm{D}$ insufficiency was present in the majority of our HIE infants, and half of these infants had decreasing $25(\mathrm{OH})$ $\mathrm{D}$ over the initial $72 \mathrm{~h}$ of treatment, in spite of administration of $417 \mathrm{ng} / \mathrm{h}$ ergocalciferol in TPN, which did not appreciably increase serum $25(\mathrm{OH}) \mathrm{D}$ concentrations. These data agree with the findings in a Turkish cohort of hypothermic mild to moderate HIE infants, in whom the incidence of serum $25(\mathrm{OH}) \mathrm{D}<5 \mathrm{ng} / \mathrm{ml}$ increased from day 1 to 5 , and was significantly greater at day 5 than in the healthy term controls (10). In our cohort, hypothermia treatment did not affect either $25(\mathrm{OH}) \mathrm{D}$ or $1,25(\mathrm{OH})_{2} \mathrm{D}$ serum concentrations compared to normothermic infants.

Vitamin D is a well-known regulator of inflammatory Tcells, and inhibits Th17 cell activation $(6,24)$. In our neonates, lowserum $25(\mathrm{OH}) \mathrm{D}$ was associated with reduced anti-inflammatory IL-17E after HIE. Another anti-inflammatory cytokine that may oppose Th17-induced inflammation, IL-27 was also correlated with $25(\mathrm{OH}) \mathrm{D}$ levels in normothermic HIE infants, providing additional evidence that vitamin $\mathrm{D}$ insufficient infants may have limited ability to mitigate post-HI Th17 inflammation. However, even in the face of low serum $25(\mathrm{OH})$ $\mathrm{D}$, hypothermia treated patients had increased IL-27, indicating direct modulation of this serum cytokine by hypothermia treatment (14). These data suggest the immunoregulation of TH17 activation after HIE depends on the mediator, with IL-17E primarily affected by vitamin D deficiency, while IL-27 was primarily affected by hypothermia therapy.

Serum 25(OH)D also serves as the main source for local CNS production of $1,25(\mathrm{OH})_{2} \mathrm{D}$. Similar to our study in neonates with HIE, serum $25(\mathrm{OH}) \mathrm{D}$ concentrations are known to decrease after stroke in adults (25). Although serum 25(OH)D has a 2 wk half-life under physiologic conditions (26), inflammation contributes to accelerated depletion of serum $25(\mathrm{OH})$ $\mathrm{D}$, which in turn limits $1,25(\mathrm{OH})_{2} \mathrm{D}$ production by leukocytes and neural cells $(8,11,12)$. The net effect of increased vitamin D metabolism in inflamed CNS tissue is to reduce the circulating substrate, $25(\mathrm{OH}) \mathrm{D}(12)$, while circulating $1,25(\mathrm{OH})_{2} \mathrm{D}$ may initially be more stably maintained.

Urinary losses may contribute to low or decreasing serum 25(OH)D concentrations in HIE infants. HI-induced renal injury is common, involves tubular dysfunction with proteinuria, and takes days to resolve. Renal reabsorption of $25(\mathrm{OH})$ D-bound DBP occurs in proximal tubular cells upon binding to megalin, a transmembrane receptor found on many cell types, including brain capillary endothelial cells, neurons and astrocytes (27). Ischemia reperfusion down-regulates renal megalin expression (28), which may result in excessive urinary losses of vitamin D and DBP (29). As DBP binds 25(OH)D with higher affinity than $1,25(\mathrm{OH})_{2} \mathrm{D}$, renal injury after $\mathrm{HI}$ birth may not have the same effect on serum $1,25(\mathrm{OH})_{2} \mathrm{D}(12)$. In fact, the tight correlation of serum $25(\mathrm{OH}) \mathrm{D}$ and $\mathrm{DBP}$ at $0-12 \mathrm{~h}$ is consistent with either urinary loss of the bound $25(\mathrm{OH}) \mathrm{D}$ or tissue distribution. One of the limitations of this study is a lack of urine samples to verify urinary losses of DBP and 25(OH)D in our patients.

Taken together, our data and other studies of vitamin D in stroke suggest that $\mathrm{HI}$ injury increases the conversion of $25(\mathrm{OH}) \mathrm{D}$ to $1,25(\mathrm{OH})_{2} \mathrm{D}$, and both $1,25(\mathrm{OH})_{2} \mathrm{D}$ and $25(\mathrm{OH})$ $\mathrm{D}$ may be subject to increased degradation as shown poststroke and in neuroinflammatory conditions $(8,30)$. Along with increased urinary losses (12), uptake of $25(\mathrm{OH}) \mathrm{D}$ into tissues for intracellular production of $1,25(\mathrm{OH})_{2} \mathrm{D}$, may also contribute to low and declining $25(\mathrm{OH}) \mathrm{D}$ serum concentrations $(12,31)$. Although we did not obtain serum samples from time points later than $72 \mathrm{~h}$, with evidence of insufficient serum $25(\mathrm{OH}) \mathrm{D}$ levels regardless of $25(\mathrm{OH}) \mathrm{D}$ supplementation, it is possible that at some point in the first days or week of life, the uptake of $25(\mathrm{OH}) \mathrm{D}$ and conversion to $1,25(\mathrm{OH})_{2} \mathrm{D}$ in neural and immune cells may be compromised in some HIE infants.

$25(\mathrm{OH}) \mathrm{D}$ insufficiency is under-recognized in HIE, and is not part of standard of care HIE protocols in research or clinical practice $(32,33)$. Our data indicate the vitamin D insufficiency is present in more than 70\% of HIE infants on admission, and may not be significantly improved by vitamin D supplementation in TPN. Both human and animal investigations indicate that pre-existing vitamin $\mathrm{D}$ deficiency exacerbates neurological injuries, and severe $25(\mathrm{OH}) \mathrm{D}$ deficiency is associated with increased stroke risk and worse outcomes in both adult humans and rodent models $(1,2,30,34,35)$. Even in the absence of HI, vitamin D deficiency during a critical perinatal window in rodent models results in behavioral and learning deficits $(36,37)$. Thus, $25(\mathrm{OH}) \mathrm{D}$ insufficiency could be an aggravating factor after neonatal HIE. Although 25(OH)D concentrations were not independently associated with survival in our infants, only two of our infants had 25(OH)D levels $\geq 30 \mathrm{ng} / \mathrm{ml}$, and we were not able to analyze neurodevelopmental outcomes by degree of 25(OH)D insufficiency due to sample size. Vitamin $\mathrm{D}$ effects may also have been overshadowed by the marked severity of HI injury in this cohort, with greater than $70 \%$ of infants with severe HIE. 
By convention, we define "sufficiency" and "insufficiency" for circulating 25(OH)D levels according to previous reports in neonatal blood using established endocrine concentrations for bone growth and homeostasis (15). However, the circulating levels of 25(OH)D that are sufficient or deficient for neurodevelopment or other intracrine roles after injury have yet to be determined. Circulating $25(\mathrm{OH}) \mathrm{D}$ concentrations required for immune function appear to be significantly higher than for bone homeostasis $(20 \mathrm{ng} / \mathrm{ml})$ and prevention of rickets $(10 \mathrm{ng} /$ ml) (15). In addition, the relationship of DBP and whether it limits the tissue bioavailability of free, unbound $25(\mathrm{OH}) \mathrm{D}$ in the serum or enhances uptake in disease states, such as neonatal HI, have not been explored (12). DBP also has independent roles as a macrophage activating factor and scavenger of extracellular actin, unrelated to its vitamin D ligand function, and seems to be independently regulated by hypothermia at $36 \mathrm{~h}$, as we have shown with other serum chemotactic factors $(14,38,39)$.

Vitamin D deficiency can result in increased Th17 cell activation (40), while treatment with vitamin $\mathrm{D}$ downregulates Th17 activation (6). In HIE neonates, 25(OH)D levels correlated with circulating Th17 inhibitory cytokines IL-17E and IL-27, but for IL-27, this effect was overridden by hypothermia treatment itself. Hypothermia upregulated anti-inflammatory IL-27 production and release from antigen presenting cells in the serum from 36 to $72 \mathrm{~h}$, even while the total circulating leukocyte, neutrophil, lymphocyte, and monocyte counts were decreasing (39). Thus, increased circulating anti-inflammatory cytokines, such as IL-17E and IL-27, may contribute to the neuroprotective mechanisms of hypothermia and yet be impacted by $25(\mathrm{OH}) \mathrm{D}$ levels.

In conclusion, this study provides insights into $25(\mathrm{OH}) \mathrm{D}$ insufficiency and effects in infants with HIE and under hypothermic conditions over the first $72 \mathrm{~h}$. Without routine monitoring, vitamin $\mathrm{D}$ insufficiency goes largely undiagnosed in neonatal HIE. Our data indicate that $25(\mathrm{OH}) \mathrm{D}$ insufficiency is common on admission and may decline further during the acute phase after HI injury. As treatment with vitamin D has been shown to provide neuroprotection in animal models of neonatal $\mathrm{HI}$ and in a small pilot trial in human adults after stroke $(41,42)$, the potential for beneficial effects of vitamin D replacement in this at risk population deserve further study.

\section{SUPPLEMENTARY MATERIAL}

Supplementary material is linked to the online version of the paper at http:// www.nature.com/pr

\section{STATEMENT OF FINANCIAL SUPPORT}

This work was supported by National Institutes of Neurologic Disorders and Stroke R01 NS38602.

Disclosure: The authors have nothing to disclose.

\section{REFERENCES}

1. Daumas A, Daubail B, Legris N, et al. Association between admission serum 25-hydroxyvitamin D levels and functional outcome of thrombolyzed stroke patients. J Stroke Cerebrovasc Dis 2016;25:907-13.

2. Park KY, Chung PW, Kim YB, et al. Serum vitamin D status as a predictor of prognosis in patients with acute ischemic stroke. Cerebrovasc Dis 2015;40:73-80.
3. Li Q, Wang Y, Yu F, et al. Peripheral Th17/Treg imbalance in patients with atherosclerotic cerebral infarction. Int J Clin Exp Pathol 2013;6:1015-27.

4. Hu Y, Zheng Y, Wu Y, Ni B, Shi S. Imbalance between IL-17A-producing cells and regulatory $\mathrm{T}$ cells during ischemic stroke. Mediators Inflamm 2014;2014:813045.

5. Black A, Bhaumik S, Kirkman RL, Weaver CT, Randolph DA. Developmental regulation of Th17-cell capacity in human neonates. Eur J Immunol 2012;42:311-9.

6. Zhang H, Shih DQ, Zhang X. Mechanisms underlying effects of 1,25-Dihydroxyvitamin D3 on the Th17 cells. Eur J Microbiol Immunol (Bp) 2013;3:237-40

7. White JH. Regulation of intracrine production of 1,25-dihydroxyvitamin $\mathrm{D}$ and its role in innate immune defense against infection. Arch Biochem Biophys 2012;523:58-63.

8. Paintlia AS, Paintlia MK, Hollis BW, Singh AK, Singh I. Interference with RhoA-ROCK signaling mechanism in autoreactive CD4+ T cells enhances the bioavailability of 1,25-dihydroxyvitamin D3 in experimental autoimmune encephalomyelitis. Am J Pathol 2012;181:993-1006.

9. Basile LA, Taylor SN, Wagner CL, Quinones L, Hollis BW. Neonatal vitamin D status at birth at latitude 32 degrees 72': evidence of deficiency. J Perinatol 2007;27:568-71.

10. Mutlu M, Sariaydın M, Aslan Y, et al. Status of vitamin D, antioxidant enzymes, and antioxidant substances in neonates with neonatal hypoxic-ischemic encephalopathy. J Matern Fetal Neonatal Med 2016;29: 2259-63.

11. Eyles DW, Smith S, Kinobe R, Hewison M, McGrath JJ. Distribution of the vitamin $\mathrm{D}$ receptor and 1 alpha-hydroxylase in human brain. J Chem Neuroanat 2005;29:21-30.

12. Chun RF, Peercy BE, Orwoll ES, Nielson CM, Adams JS, Hewison M. Vitamin D and DBP: the free hormone hypothesis revisited. J Steroid Biochem Mol Biol 2014;144 Pt A:132-7.

13. Eicher DJ, Wagner CL, Katikaneni LP, et al. Moderate hypothermia in neonatal encephalopathy: efficacy outcomes. Pediatr Neurol 2005;32: $11-7$.

14. Jenkins DD, Rollins LG, Perkel JK, et al. Serum cytokines in a clinical trial of hypothermia for neonatal hypoxic-ischemic encephalopathy. J Cereb Blood Flow Metab 2012;32:1888-96.

15. Walker VP, Zhang X, Rastegar I, et al. Cord blood vitamin D status impacts innate immune responses. J Clin Endocrinol Metab 2011;96:1835-43.

16. Munns CF, Shaw N, Kiely M, et al. Global consensus recommendations on prevention and management of nutritional rickets. J Clin Endocrinol Metab 2016;101:394-415.

17. Kramer CK, Ye C, Hanley AJ, et al. The relationship between parathyroid hormone and 25-hydroxy vitamin D during and after pregnancy. J Clin Endocrinol Metab 2016:jc20154060.

18. Hoogenboezem T, Degenhart HJ, de Muinck Keizer-Schrama SM, et al. Vitamin D metabolism in breast-fed infants and their mothers. Pediatr Res 1989;25:623-8.

19. Hanson C, Lyden E, Nelson A, et al. Response of vitamin $D$ binding protein and free vitamin $\mathrm{D}$ concentrations to vitamin $\mathrm{D}$ supplementation in hospitalized premature infants. J Pediatr Endocrinol Metab 2015;28:1107-14.

20. Ikeda U, Wakita D, Ohkuri T, et al. 1 $\alpha, 25$-Dihydroxyvitamin D3 and alltrans retinoic acid synergistically inhibit the differentiation and expansion of Th17 cells. Immunol Lett 2010;134:7-16.

21. Waisman A, Hauptmann J, Regen T. The role of IL-17 in CNS diseases. Acta Neuropathol 2015;129:625-37.

22. Kraft JD, Horzempa J, Davis C, Jung JY, Peña MM, Robinson CM. Neonatal macrophages express elevated levels of interleukin-27 that oppose immune responses. Immunology 2013;139:484-93.

23. Chang JH, Cha HR, Lee DS, Seo KY, Kweon MN. 1,25-Dihydroxyvitamin D3 inhibits the differentiation and migration of $\mathrm{T}(\mathrm{H}) 17$ cells to protect against experimental autoimmune encephalomyelitis. PLoS One 2010;5:e12925.

24. Baeke F, Korf H, Overbergh L, et al. Human T lymphocytes are direct targets of 1,25-dihydroxyvitamin D3 in the immune system. J Steroid Biochem Mol Biol 2010;121:221-7.

25. Sato Y. Abnormal bone and calcium metabolism in patients after stroke. Arch Phys Med Rehabil 2000;81:117-21. 


\section{Articles | Lowe et al.}

26. Jones KS, Assar S, Harnpanich D, et al. $25(\mathrm{OH}) \mathrm{D} 2$ half-life is shorter than 25(OH)D3 half-life and is influenced by DBP concentration and genotype. J Clin Endocrinol Metab 2014;99:3373-81.

27. Alvira-Botero X, Pérez-Gonzalez R, Spuch C, et al. Megalin interacts with APP and the intracellular adapter protein FE65 in neurons. Mol Cell Neurosci 2010;45:306-15.

28. Schreiber A, Theilig F, Schweda F, Höcherl K. Acute endotoxemia in mice induces downregulation of megalin and cubilin in the kidney. Kidney Int 2012;82:53-9.

29. Anderson RL, Ternes SB, Strand KA, Rowling MJ. Vitamin D homeostasis is compromised due to increased urinary excretion of the 25-hydroxycholecalciferol-vitamin D-binding protein complex in the Zucker diabetic fatty rat. Am J Physiol Endocrinol Metab 2010;299:E959-67.

30. Balden R, Selvamani A, Sohrabji F. Vitamin D deficiency exacerbates experimental stroke injury and dysregulates ischemia-induced inflammation in adult rats. Endocrinology 2012;153:2420-35.

31. Di Rosa M, Malaguarnera M, Nicoletti F, Malaguarnera L. Vitamin D3: a helpful immuno-modulator. Immunology 2011;134:123-39.

32. Committee on Fetus and Newborn; Papile LA, Baley JE, Benitz W, et al. Hypothermia and neonatal encephalopathy. Pediatrics 2014; 133:1146-1150.

33. Olsen SL, Dejonge M, Kline A, et al. Optimizing therapeutic hypothermia for neonatal encephalopathy. Pediatrics 2013;131:e591-603.

34. Brøndum-Jacobsen P, Nordestgaard BG, Schnohr P, Benn M. 25-hydroxyvitamin D and symptomatic ischemic stroke: an original study and metaanalysis. Ann Neurol 2013;73:38-47.
35. Turetsky A, Goddeau RP Jr, Henninger N. Low serum vitamin D is independently associated with larger lesion volumes after ischemic stroke. J Stroke Cerebrovasc Dis 2015;24:1555-63.

36. Harms LR, Eyles DW, McGrath JJ, Mackay-Sim A, Burne TH. Developmental vitamin D deficiency alters adult behaviour in 129/SvJ and C57BL/6J mice. Behav Brain Res 2008;187:343-50.

37. Wrzosek M, Łukaszkiewicz J, Wrzosek M, et al. Vitamin D and the central nervous system. Pharmacol Rep 2013;65:271-8.

38. Delanghe JR, Speeckaert R, Speeckaert MM. Behind the scenes of vitamin D binding protein: more than vitamin D binding. Best Pract Res Clin Endocrinol Metab 2015;29:773-86.

39. Jenkins DD, Lee T, Chiuzan C, et al. Altered circulating leukocytes and their chemokines in a clinical trial of therapeutic hypothermia for neonatal hypoxic ischemic encephalopathy ${ }^{\star}$. Pediatr Crit Care Med 2013;14:78695.

40. Bruce D, Yu S, Ooi JH, Cantorna MT. Converging pathways lead to overproduction of IL-17 in the absence of vitamin D signaling. Int Immunol 2011;23:519-28.

41. Kajta M, Makarewicz D, Ziemińska E, et al. Neuroprotection by co-treatment and post-treating with calcitriol following the ischemic and excitotoxic insult in vivo and in vitro. Neurochem Int 2009;55:265-74.

42. Gupta A, Prabhakar S, Modi M, et al. Effect of vitamin D and calcium supplementation on ischaemic stroke outcome: a randomised controlled open-label trial. Int J Clin Pract 2016;70:764-70. 